\title{
Budd-Chiari syndrome in a young patient with anticardiolipin antibodies: need for prolonged anticoagulant treatment
}

Department of Internal Medicine, Ikazia Hospital, Rotterdam, The Netherlands R J Th Ouwendijk J C Koster

Departments of Internal Medicine, Hematology, Radiology, Gynecology, Dijkzigt Hospital, Rotterdam, The Netherlands J H P Wilson J Stibbe J S Lameris W Visser

Service D'hepatologie, Hospital Beaujon, Clichy, France J-P Benhamou

Correspondence to: Dr R J Th Ouwendijk, Department of Internal Medicine, Ikazia Hospital, Montessoriweg 1, 3083 AN Retherlands.

Accepted for publication 28 October 1993

\begin{abstract}
The case of a 20 year old woman is reported with Budd-Chiari syndrome in whom lupus anticoagulant and anticardiolipin antibodies were shown; treatment with oral anticoagulants induced a considerable improvement. This treatment was interrupted after one year; interruption was followed by redevelopment of ascites. Further treatment with anticoagulants was continued for five years with noticeable improvement. When treatment with oral anticoagulants was stopped because of pregnancy, the patient redeveloped ascites and had a spontaneous miscarriage. Subsequently, treatment with oral anticoagulants was reintroduced and again resulted in noticeable improvement. In conclusion patients with BuddChiari syndrome should be tested for lupus anticoagulants and anticardiolipin antibodies, Budd-Chiari syndrome resulting from this cause may have a good response to treatment with oral anticoagulants; this treatment should be maintained permanently, and pregnancy in such patients may initiate serious difficulties.
\end{abstract}

(Gut 1994; 35: 1004-1006)

Hepatic venous outflow block or Budd-Chiari syndrome is a severe liver disease with a three year survival rate of $50 \% .{ }^{1}$ Several conditions have been implicated as a cause of BuddChiari syndrome, including myeloproliferative disorders, ${ }^{2}$ paroxysmal nocturnal haemoglobinuria, ${ }^{3}$ the presence of lupus anticoagulant, ${ }^{4-6}$ oral contraceptives, ${ }^{7}$ pregnancy, ${ }^{8}$ and others. ${ }^{9} 10$ In a small number of cases Budd-Chiari syndrome is associated with the presence of lupus anticoagulant. ${ }^{4-6}$ Anticardiolipin antibodies are similar to lupus anticoagulant antiphospholipid antibodies, which have been described in patients with recurrent arterial and venous thrombosis, thrombocytopenia, fetal loss or miscarriage. This syndrome has been called the antiphospholipid antibody syndrome. ${ }^{11}$ We report a case of Budd-Chiari syndrome in a young woman with both lupus anticoagulant and anticardiolipin antibodies, who responded to oral anticoagulation and remained well for five years. When the patient became pregnant, however, and oral anticoagulants were stopped she redeveloped ascites and intrauterine fetal death occurred.

\section{Case report}

A 20 year old woman was well until two weeks before admission, when she developed right upper abdominal pain, vomiting, and fever. She had been taking oral contraceptives for several years. On admission, she had a normal blood pressure, body temperature of $38^{\circ} \mathrm{C}$, and tenderness in the right upper abdomen, no signs of ascites were noted. Laboratory examination showed the following values: haemoglobin $5.9 \mathrm{mmol} / \mathrm{l}$; packed cell volume $40 \%$; white blood cell count $6.4 \times 10^{9} / 1$; platelet count $1.8 \times 10^{9} / 1$; reticulocytes $5 \%$; prothrombin time $13.0 \mathrm{~s}$ (control, $11 \mathrm{~s}$ ); activated partial thromboplastin time (aPTT) $41 \mathrm{~s}$ (control 30-39 s), serum alanine aminotransferase $18 \mathrm{U} / \mathrm{ml} \quad(\mathrm{N}<30)$ alkaline phosphatase $41 \mathrm{U} / 1 \quad(\mathrm{~N}=120), \gamma$-glutamyltransferase $57 \mathrm{U} / 1(\mathrm{~N}<30)$, total bilirubin 37 $\mu \mathrm{mol} / \mathrm{l}$.

Ultrasonography showed a thickened gall bladder wall, which was tender.

On the probable diagnosis of acalculous cholecystitis, a laparotomy was performed. The gall bladder was normal. The right liver lobe was red and swollen, the spleen slightly enlarged, there was no ascites. A biopsy specimen was taken from the right lobe of the liver, which showed only dilated sinusoids.

Two weeks later she developed ascites with a protein content of $2 \mathrm{~g} / \mathrm{l}$. During venous angiography of the hepatic veins, only the vein of the caudate lobe could be visualised. The inferior cava was patent, the free hepatic venous pressure was $14 \mathrm{~mm} \mathrm{Hg}$, wedged hepatic venous pressure $30 \mathrm{~mm} \mathrm{Hg}$, and right atrial pressure $14 \mathrm{~mm} \mathrm{Hg}$. By magnetic resonance imaging the left and middle hepatic vein and a collateral vessel draining the right liver lobe

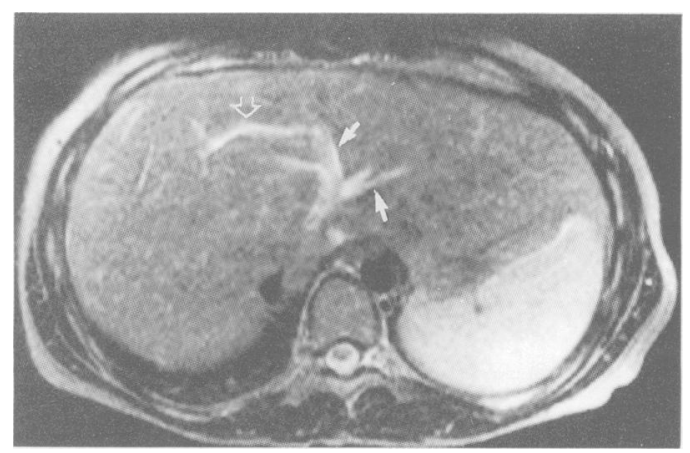

$T^{2}$ weighted (TR 2000, TE 90) section at the level of the hepatic veins entering the inferior caval vein. The left and middle hepatic veins (arrows) and a collateral vessel (open arrow) draining the right liver lobe are visualised as bright structures. The right hepatic vein is obliterated. 
were visualised. The right hepatic vein was obliterated (Figure).

Further investigation of the cause of the Budd-Chiari syndrome was performed. Antibodies against extractable nuclear antigen, antinuclear antibodies, rheumatoid factor, and Treponema palladium haemaglutination antibodies could not be detected. The direct and indirect Coombs' test and Ham's test were negative. Antithrombin III, protein S and C concentrations were normal. The prothrombin time was normal, while aPTT was slightly raised. Lupus anticoagulant and anticardiolipin antibodies were found. Culture of bone marrow with and without erythropoietin showed a normal growth pattern. We concluded that this patient had a Budd-Chiari syndrome because of lupus anticoagulant and anticardiolipin antibodies. Ascites was successfully treated with paracentesis and diuretics. Coumarin treatment was started. After six months, the diuretics were stopped without recurrence of ascites. After one year we decided to stop the oral anticoagulants.

Within a month she redeveloped ascites. After the oral anticoagulation treatment and diuretics were started again, she remained well for another five years. Repeat magnetic imaging showed no progression of the BuddChiari syndrome. She then wanted to have a baby despite having been informed of the risk of deterioration of the Budd-Chiari syndrome and obstetrical complications.

After several months, she returned because of an amenorrhoea of four weeks' duration. The oral anticoagulants were stopped; heparin 7.500 IE twice daily subcutaneously was started. Fourteen days later she had the same complaints as at the first admission five years previously. On physical examination no abnormalities were found. Laboratory investigation showed several abnormalities. Haemoglobin, $6.7 \mathrm{mmol} / \mathrm{l}$; packed cell volume, $45 \%$; white blood cell count, $2 \times 10^{9} / 1$; platelet count $5.6 \times 10^{9} /$; prothrombin time, $13 \mathrm{~s}$; aPTT, $43 \mathrm{~s}$; fibrinogen $4.6 \mathrm{~g} /$; fibrin degradation products, $200 \mu \mathrm{g} / \mathrm{l}$. The lupus anticoagulant test was positive, IgG anticardiolipin antibodies were positive $98 \mathrm{IU} / 1$ (normal $0-31$ ) as were IgM anticardiolipin antibodies 26 IU/1 (normal 0-12); ultrasonography showed a uterus of six weeks pregnancy with no signs of fetal heart action. Treatment with intravenous heparin and prednisone $80 \mathrm{mg}$ daily was started. Ascites was successfully treated with diuretics. In the following days spontaneous miscarriage occurred. Within six weeks all laboratory results returned to normal. Two months after the miscarriage, she was well. Platelet count was $140 \times 10^{9} / 1$ with $25 \mathrm{mg}$ prednisone daily, a reduction to $20 \mathrm{mg}$ daily was followed by an acute drop of the platelet count to $43 \times 10^{9} / 1$, which became normal after treatment with $60 \mathrm{mg}$ prednisone daily. At 12 months after the miscarriage she did not have ascites, although she had stopped using diuretics, and platelet count was $141 \times 10^{9} / 1$ (with $5 \mathrm{mg}$ prednisone daily). The patient still had high concentrations of IgG anticardiolipin antibodies $81 \mathrm{IU} / 1$ and IgM anticardiolipin antibodies 17 IU/1.

\section{Discussion}

The aetiology of the Budd-Chiari syndrome can be classified in five groups according to the mechanism of obstruction, namely primary lesions of the main hepatic veins, benign or malignant invasion of the hepatic veins, obstruction of the inferior vena cava, and veno occlusive disease. ${ }^{12} 13$

In our patient computed tomography and magnetic resonance imaging showed thrombosis of two hepatic veins. Thrombosis of the hepatic veins can result from an underlying primary myeloproliferative disorder, ${ }^{2}$ the use of oral contraceptives, ${ }^{7}$ pregnancy, ${ }^{8}$ postpartum state, ${ }^{14}$ paroxysmal nocturnal haemoglobinuria, ${ }^{3}$ the presence of lupus anticoagulant, and several miscellaneous disorders such as connective tissue diseases. ${ }^{910}$ A myeloproliferative disorder was excluded by a normal bone marrow aspirate and normal colony formation of the erythroid cells in an erythropoietin poor medium. A normal acid Ham's test, normal coagulation parameters apart from a prolonged aPTT and negative rheumatoid and lupus erythematosus serology in our patient excluded paroxysmal nocturnal haemoglobinuria, diffuse intravascular coagulation, and rheumatic disorders.

In our patient two possible causes for the hepatic vein thrombosis were found, namely the use of oral contraceptives and the presence of lupus anticoagulant and anticardiolipin antibodies. Longterm use of oral contraceptives increases the risk of venous thrombosis by exacerbating an underlying thrombogenic condition such as paroxysmal nocturnal haemoglobinuria or a myeloproliferative disease. ${ }^{2} 715$ As mentioned such abnormalities were not found in this patient. The most likely cause in our patient is therefore the lupus anticoagulant and anticardiolipin antibodies. Lupus anticoagulant and anticardiolipin antibodies are both antiphospholipid antibodies. ${ }^{11} 1617$

Antiphospholipid antibodies are associated with venous and arterial thrombosis and recurrent miscarriage. ${ }^{11} 17$

Lupus anticoagulant is an immunoglobulin of IgG or IgM class with a tendency to adhere to the phospholipid portion of the prothrombin activator complex resulting in prolongation of the aPTT. At presentation and during pregnancy our patient had a prolonged aPTT, with detectable lupus anticoagulant and anticardiolipin antibodies.

Anticardiolipin antibodies are of the IgM, IgG, or IgA classes and can be quantified by a radioimmunoassay. Anticardiolipin antibodies are also associated with arterial and venous thrombosis, cerebral thrombosis, thrombocytopenia, recurrent miscarriages, endocardial lesions in systemic lupus erythematosus, and giant cell arteritis. ${ }^{18} 19$ In $70 \%$ of the patients both lupus anticoagulant and anticardiolipin antibodies are present. High concentrations of anticardiolipin antibodies are closely correlated with severe complications such as thrombosis, thrombocytopenia, and a variety of obstetrical problems. ${ }^{1120}$

Tests for anticardiolipin antibodies are possibly of greater value than tests for lupus 
anticoagulant, because they are more sensitive and less subject to interobserver errors or variations in methodology than tests for lupus anticoagulant. ${ }^{11} 20-25$

The treatment of choice in patients with Budd-Chiari and the presence of lupus anticoagulant and anticardiolipin antibodies is coumarin anticoagulation. ${ }^{4622}$ Our patient was successfully treated by coumarin anticoagulation; ascites was treated by paracentesis and diuretics. It was possible to stop the diuretics after six months of treatment.

The longterm prognosis of patients with the Budd-Chiari syndrome resulting from lupus anticoagulants is not well known. Several reports with long survival after the diagnosis have been described; however, rapid deterioration and death have also been reported. ${ }^{4-6}$

Pregnancy is a risk factor for the development of Budd-Chiari syndrome; but, on the other hand, several cases of successful pregnancy in patients with the Budd-Chiari syndrome have been reported. ${ }^{26}$ The presence of lupus anticoagulant and the high concentrations of anticardiolipin are associated with venous and arterial thrombosis, increased fetal loss or recurrent miscarriage. ${ }^{11} 1720$ Despite being warned about the risks our patient became pregnant and despite subcutaneous heparin the patient had a miscarriage at six weeks of pregnancy and developed ascites and severe thrombocytopenia.

High concentrations of IgG anticardiolipin antibodies are closely correlated by recurrent fetal loss, thrombocytopenia, and thrombosis and have a high predictive value of renewed problems in subsequent pregnancies. ${ }^{1123}$ Our patient has high IgG anticardiolipin antibodies, suggesting again problems in another pregnancy. To prevent complications in patients with lupus anticoagulant and high concentrations of anticardiolipin antibodies some have advocated aspirin, heparin, and corticosteroids. 2023242728 The role of corticosteroids in the treatment of this condition is not clearly defined. 20222428

The good clinical response to oral anticoagulants in our patient illustrates the importance of testing patients with Budd-Chiari syndrome for anticardiolipin antibodies and lupus anticoagulant, and, if positive, of giving prolonged oral anticoagulation.

The authors thank Mrs M Awad-Langstraat for her prompt and accurate typing of the manuscript.

1 Gupta S, Blumgart LH, Hodgson HJF. Budd-Chiari syndrome: Long term survival and factors affecting mortality. $Q \mathcal{F}$ Med $1986 ; 60$ : 781-91.

2 Valla D, Casadevall N, Lacombe C, Varey B, Goldwasser E Franco D, et al. Primary myeloproliferative disorder and hepatic vein thrombosis. Ann Intern Med 1985; 103: 329-34

3 Hartman RC, Luther AB, Jenkins DE, Tenorio LE, Saba Sr. Fulminant hepatic venous thrombosis (Budd-Chiari syndrome) in paroxysmal nocturnal hemoglobinuria. A spectrum from asymptomatic occlusion of hepatic venules to fatal Budd-Chiari syndrome. Gastroenterology 1987; 93: 569-75.

4 Pomeroy C, Knodell RG, Swaim WR, Arneson P, Mahowald ML. Budd-Chiari syndrome in a patient with the lupus anticoagulant. Gastroenterology 1984; 86: 158-61.

5 Terabayashi H, Okuda K, Nomura F, Ohnishi K, Wong P. Transformation of inferior vena caval thrombosis to membranous obstruction in a patient with the lupus anticoagulant. Gastroenterology 1986; 91: 219-24.

6 Steenbergen W, Beyls J, Vermijlen J, Fevery J, Marchal G Desmet V, et al. Lupus anticoagulant and thrombosis of the hepatic veins (Budd-Chiari syndrome). $\mathcal{f}$ Hepatol 1986; 3: 87-94.

7 Valla D, Le MG, Poynard T, Zucman N, Rueff B Benhamou JP. Risk of hepatic vein thrombosis in relation to recent use of oral contraceptives. Gastroenterology 1986; 90: 807-11.

8 Khuroo MS, Datta DV. Budd-Chiari syndrome following pregnancy. Report of 16 cases, with roentgenologic, hemodynamic and histologic studies of the hepatic outflow tract. $A m \mathfrak{f}$ Med 1980; 68: 113-21.

9 Wilkey D, Yocum DE, Oberley TD, Stundstrom WR, Karl L. Budd-Chiari syndrome and renal failure in Behcet's disease. Am ₹ Med 1983; 75: 413-22.

10 Disney TF, Sullivan SN, Haddad RG, Lowe D, Goldbach MM. Budd-Chiari syndrome with inferior vena cava obstruction associated with systemic lupus erythematosus. f Clin Gastroenterol 1984; 6: 253-6.

1 Harris EN, Chan JKH, Asherson RA, Aber VR, Gharavi AE, Hughes GRV. Thrombosis, recurrent fetal loss and thrombocytopenia. Arch Intern Med 1986; 146: 2153-6.

12 Ludwig J, Hashimoto E, McGill DB, Heerden JA Classification of hepatic venous outflow obstruction ambiguous terminology of the Budd-Chiari syndrome. Mayo Clin Proc 1990; 38: 53-5.

13 Benhamou IP, Valla D. Disorders of the hepatic veins and venules. In: Okuda $\mathrm{K}$, Benhamou JP, eds. Portal hypertension clinical and physiological aspects. Tokyo: Springer tension clinical and physiot

14 Ilan Y, Oren R, Shouval D. Postpartum Budd-Chiari syndrome with prolonged hypercoagulability state. $A m \mathcal{f}$ Obstet Gynecol 1990; 162: 1164-5.

15 Lalond G, Theoret G, Daloze P, Bettez P, Katz SS. Inferior vena cava stenosis and Budd-Chiari syndrome in a woman taking oral contraceptives. Gastroenterology 1982; 82: 1452-6.

16 Harris EN, Boey ML, Mackworth-Young CG, Gharavi AE, Patel BM, Loizou S, et al. Anticardiolipin antibodies: detection by radio-immunoassay and association with thrombosis in systemic lupus erythematosus. Lancet 1983; ii: $1211-4$.

17 Carreras LO, Defreyn G, Machin SJ. Arterial thrombosis intrauterine death and lupus anticoagulant: detection of
immunoglublin interfering with prostacyclin formation. immunoglublin interfe 1981 ; i: $244-6$.

18 Khamashta MA, Cervera R, Asherson RA, Font J, Gil A, Coltart DJ, et al. Association of antibodies against phospholipids with heart valve disease in systemic lupus erythematosus. Lancet 1990; 335: 1541-7.

19 Espinoza LR, Jara LJ, Silveira LH, Martinez-Oshuna P, Zwolinska JB, Kneer C, et al. Anticardiolipin antibodies in polymyalgia rheumatica - giant cell arteritis: association with severe vascular complications. Am $f$ Med 1991; 90: w74-8.

20 Silveira LH, Hubble CL, Jara LJ, Saway S, MartinezOsuma P, Seleznick MJ, et al. Prevention of anticardiOsuma P, Seleznick MJ, et al. Prevention of anticardiolipin antibody-related pregnancy losses with
and aspirin. $A m \mathcal{F M e d}$ 1992; 93: 403-11.

21 Exner T, Richard KA, Kronenberg HA. Sensitive test demonstrating lupus anticoagulant and its behavioural patterns. Br f Haematol 1978; 40: 143-51.

22 Reece EA, Gabrielli S, Cullen MT, Xue-Zhong Zheng, Hobbins JC, Harris EN. Recurrent adverse pregnancy outcome and antiphospholipid antibodies. Am $\mathcal{F}$ Obstet Gynecol 1990; 163: 162-9.

23 Lockshin D, Druzin ML, Goei S, Quamar T, Magid MS, Jovanovic L, et al. Antibody to cardiolipin as a predictor of fetal distress or death in pregnant patients with systemic lupus erythematosus. $N$ Engl $\mathcal{F}$ Med 1985; 313: 152-6.

24 Triplett DA, Harris EN. Antiphospholipid antibodies and riplett DA, Harris EN. Antiphospholipid antibodies and
reproduction. Am $\mathcal{F}$ Reprod Immunol 1989; 21: 123-31.

25 Gastineau DA, Kazier FJ, Nichols WL, Bowie EJ. Lupus anticoagulant, an analysis of the clinical and laboratory features of 219 cases. Am $\mathcal{F}$ Hematol 1985; 19: 265-75.

26 Vons C, Smadja C, Franco D, Valla D, Rueff B, Benhamou JP. Successful pregnancy after Budd-Chiari syndrome. Lancet 1984; ii: 975.

27 Branch DW, Scott JR, Kochenour NK, Hershgold E. Obstetric complications associated with the lupus anticoagulant. N Engl f Med 1985; 313: 1322-6.

28 Rosove MH, Brewer PMC. Antiphospholipid thrombosis: clinical course after the first thrombotic event in 70 patients. Ann Intern Med 1992; 117: 303-8. 